\title{
Property effects. Social networks and compensation claims in Melanesia
}

This paper compares the social networks that are mobilised through claims of ownership in property regimes and transaction regimes. ${ }^{1}$ I use the categories of 'property' and 'transaction' to denote the differences between exchange practices that emphasise relationships between persons and things (property) in contrast to relationships created between persons through the circulation of things (transactions). This distinction attends to the social networks that are formed as a consequence of exchange, providing an alternative to the opposition between gifts and commodities (e.g. Gregory 1982). Critics of this dichotomy have objected to its application to entire societies, citing the complementarity of the two modes of exchange within societies (Carrier 1995: viii). Other critics have examined the processes through which gifts can be converted into commodities and vice-versa, resulting in arguments about the 'commodity potential' of all things (Appadurai 1988: 13). In contrast, I am interested in the social consequences of different modes of exchange. Not all exchange practices, for example, contribute to the 'reproduction of the social and cosmic order', as Bloch and Parry (1991: 2; see also Weiner 1980) have argued. The distinction between property and transaction regimes emphasises the social networks associated with different strategies of ownership, rather than the status of particular objects as gifts or commodities.

I examine these differences in relation to compensation claims for damage and destruction to property that have been levied against the Lihir gold mine in Papua

1 Support for this research was provided by the Center for International Business Education at the University of Michigan and the UK Economic and Social Research Council in association with the 'Property, Transactions and Creativity' project directed by Marilyn Strathern and Eric Hirsch. I thank Martin Paining and Leonard Lagisa for their assistance on Lihir, as well as the people who participated in interviews there. I am particularly grateful to Martha Macintyre for generously sharing insights drawn from applied research on Lihir, and for permission to cite her unpublished work. A related paper discussing these examples previously appeared as 'Keeping the network in view. Compensation, property and social relations in Melanesia', in L. Kalinoe and J. Leach (eds.), Rationales of ownership, New Delhi: UBS Publishers' Distributors Ltd. and Port Moresby: Law Faculty Publication Unit, University of Papua New Guinea, 2001. That volume considers the implications of different strategies of ownership for policy and legislation on cultural and intellectual property rights in Papua New Guinea. Thanks are also due to Tony Crook, Eric Hirsch, James Leach, Marilyn Strathern, Michael Wood and the two anonymous reviewers for Social Anthropology for their valuable comments, suggestions and criticisms. Any errors of fact or interpretation are solely my responsibility. 
New Guinea. ${ }^{2}$ I focus on the difference between Lihirian ideas about property, exchange and social networks, and those enshrined in Euro-American business practices. In the Euro-American examples, ownership strategies promote rights on the basis of exclusion, limiting alternative claims to property (Strathern 1996). In contrast, Lihirian claims generally seek to bring longer social networks into view, expanding the possibilities for participation. I also suggest that disputes between the mine and Lihirians regarding compensation claims are related in part to the tension between the two regimes of exchange. Lihirians participate in a divided economy in which social reproduction through mortuary exchange is carried out through transactions which emphasise social relations. One of the challenges faced by Lihirians is how to perpetuate local ways of establishing value and reproducing social relationships while fully participating in the cash economy associated with the mine.

\section{Property effects}

The objective of this paper is to assess how different strategies of ownership affect other social categories and practices. This question was recently raised by William Pietz (1997: 98) in an essay that addressed the 'sweeping transformation in British social institutions of the 1840 s that established legal structures better suited to capitalist enterprise and liberal society'. His focus was the abolition of the legal principle of the deodand, which held that an object that causes a person's death, such as a farm animal that tramples a neighbour, the knife used to commit a murder, or more significantly for this paper, the locomotive that kills an individual crossing the railway tracks, must be forfeited to the sovereign. The emergence of railways as nineteenthcentury economic powers, Pietz argued, prompted re-evaluation of both the laws pertaining to the deodand and the broader question of how to calculate the value of compensation owed for the loss of human life. Railways could not afford to risk forfeiture of their engines or payment of the equivalent value in cash; the principle of the deodand jeopardised the industry and its multiplier effects on agriculture and textile production. Legal reforms were contingent on formulating a new means of calculating the value that would be paid in compensation for fatal accidents. Whereas the deodand established a value for compensation based on the worth of the material object that was instrumental in causing the death, rescinding this principle prompted a shift to the evaluation of what had been lost, establishing an economic value for human life. Pietz revealed the connections between new technologies, new kinds of property claims (in compensation for the loss of life) and new social categories (the creation of a money value for human life). New forms of property may alter fundamental social categories, including how one imagines life itself.

Whereas Pietz examined an historical turning point in British definitions of property and persons, this paper focuses on the conjunction of two different systems for

2 This paper has an unusual history. I visited Lihir during a three-week investigation of property and social relations in Papua New Guinea from the miner's point of view. Due to circumstances beyond my control, my stay on Lihir was limited to a single day. Given the significance of the issues raised in those interviews for debates about mining and compensation in Papua New Guinea, and the questions they raise for anthropologists, I have elected to present this information, supplemented by written records to which I was given access by the Lihir mine. I should also note that some of the material discussed here remains controversial and some of the readers of this paper have strongly disagreed with parts of my argument. 
organising claims of ownership. In both the essay by Pietz and the examples from Lihir, however, the paired contrasts (before/after in the historical analysis and the differences between societies in the following ethnographic discussion) make explicit the relationship between strategies of ownership and other social categories. This paper also examines the implications of introducing new forms of technology (mines, roads, vehicles) that have prompted compensation claims by Lihirians. Whereas Pietz described legal reforms that favoured the interests of capital, this paper examines continued assertions of difference despite efforts by the mine to rationalise its relationships with Lihirians according to Euro-American concepts of property and propriety. The networks mobilised by their respective claims also influence how the two parties view the environmental impact of the mine, suggesting an underlying symmetry between Euro-American property models and scientific practice.

\section{Compensation on Lihir}

I present three cases that examine relations between the Lihir gold mine and local communities on Lihir, east of New Ireland. ${ }^{3}$ Two of these examples address compensation claims against the mine for the loss of pigs. ${ }^{4}$ In the first case, the death of a number of pigs from Putput village was initially attributed to pollution from the mine. Scientific investigation eventually refuted this claim, but compensation payments were made after the mine acknowledged a complex chain of events that linked its actions to the death of the pigs. The second example is concerned with pigs killed by vehicles on a road built by the mining company. It illustrates how both Lihirians and miners manipulate social networks to their own advantage, demonstrating the flexibility that exists in the application of different strategies of ownership. The final case examines values for pigs in ritual exchange that appear to be 'irrational' or non-economic unless one takes into account the social networks that are referenced by these transactions. How do the social networks associated with property regimes (the Euro-American examples) differ from those associated with transaction regimes (the Lihirian examples)? How are the resulting networks exploited by the two parties? I also consider the relationship between these social networks and the ways in which the respective parties view environmental issues associated with the mine.

Although compensation claims made against mining companies may appear initially to be an unusual context for examining how ownership claims are formulated in Melanesia, they have two distinct advantages. First, the examples provide access to both Euro-American and Lihirian ways of viewing social networks in the same milieu, facilitating comparison between the two. Second, negotiations between the miners (both expatriate and Melanesian) and local communities provide explicit commentary

3 The Lihir group of islands (Niolam, Malie, Masahet and Mahur) is located off the east coast of New Ireland, between Tabar and Tanga.

4 Negotiations between the state, the mining company and local communities resulted in a benefits package that addressed compensation for impact, relocation and infrastructure development, environmental monitoring and rehabilitation (Banks 1998: 61-2). Payments to landowners are proportionate to the level of impact from the mine, including damage to hot springs, dust from company vehicles, discolouration of sea water, impact on local fauna and the destruction of sacred sites and graves. Landowners receive royalty payments in addition to any dividends from their shares in the mine. Industry observers have described the agreement as 'the benchmark within Papua New Guinea for such arrangements' (Banks 1998: 62). 
on their respective differences. Lihirians have had to adjust to the new world created around the mine and in each of the following examples, they accomplish this in part by revealing connections to wider social networks. ${ }^{5}$

\section{Pig deaths at Putput}

In late 1999, Samuel Venge ${ }^{6}$ from Putput village in Lihir presented a compensation claim to the Lihir Management Company (henceforth, the Lihir mine), which operates the gold mine at Lihir. ${ }^{7}$ Venge sought compensation for the death of two pigs he was raising in the village, which includes property adjacent to the mine. In the heat of the afternoon, the pigs took refuge in Labarai creek, which runs behind the processing plant at the mine. Venge suggested that the animals drank from the creek. Given that run-off from the mine facility enters Labarai creek, Venge suspected that pollution from the mine killed his pigs and asked for compensation from the Lihir mine, holding it responsible for his loss. ${ }^{8}$

The mine's manager for external relations, James Makon, ${ }^{9}$ responded swiftly to Venge's claim. Makon, who is from New Ireland, previously directed community relations at the Ok Tedi mine, where communication between the mine and downstream communities has long been dominated by mistrust. That mine claimed to protect the environment, while creating one of the worst ecological disasters in the region (Hyndman 1994; Kirsch 1997a). ${ }^{10}$ Makon's experiences at Ok Tedi encouraged him to expedite the response of the Lihir mine in order to allay any suspicions that the company had something to hide. He spoke directly with Venge, negotiating the terms of the compensation, and authorised payment of K2,200, a rather large sum for two pigs by Papua New Guinea standards.

Before the year's end, however, a representative from the Lihir Mining Area Landowners Association (henceforth, landowners association) presented claims to the mine from 21 landowners regarding the recent deaths of an additional 22 pigs. What caused the mysterious demise of the pigs at Putput? Did toxic chemicals from the processing plant poison the animals? Was the mine responsible for the decimation of the

5 Writing about agency and liability in the Highlands of Papua New Guinea, Strathern and Stewart (2000: 92) emphasised the importance of 'chains of interpersonal events' in the explanation of accidents. These chains are comparable to what I mean by networks.

6 A pseudonym.

7 According to Rio Tinto (1997: 25): 'With reserves containing more than 13 million ounces of recoverable gold, Lihir is one of the world's largest known gold resources'.

8 Landowners from Lihir have previously protested against (what they perceived to be) unanticipated or unacceptable environmental impacts from the Lihir mine. On 7 July 1998, 'angry landowners from Putput village near the Lihir gold mine temporarily shut operations at the open pit' because of concerns about gas leaking from equipment at the mine (Post Courier of Papua New Guinea, 1998). According to the Post Courier, the acting managing director for the mine said: "The landowners had general concerns on the environmental impact of the operations. We were able to allay their fears and we undertook to provide them with outside expert advise" (on the environmental impacts of the plant)'.

9 A pseudonym.

10 For example, a public relations poster produced by the Ok Tedi mine in the early 1990s asserted that 'Kampani lukautim wara, bus, na abus' ['The company protects the rivers, forests and wildlife']. 
Putput pig herds? Should it compensate the owners, particularly given the precedent established by Makon with respect to Venge's pigs?

Early in the new year, a representative of the mine composed a memo which described his meeting with the villagers of Putput, who 'agreed that compensation is not the [sole] solution to their demands. We must identify [the] cause [of the pig deaths] and inform the community'. In the interim, villagers from Putput requested that a fence be constructed around the plant site to keep their remaining pigs away from Labarai creek. As another mine employee related in a separate memo, 'If we can block it [access to mine property] off ... then we will solve the problem. Their pigs can die on their own side of the fence'.

Shortly thereafter, the Lihir mine formally asked the PNG National Agriculture Quarantine and Inspection Authority to investigate the Putput pig mortalities. Dr Thompson, the Regional Veterinary Officer, Momase and Islands regions, arrived in Lihir two days later. He conducted ante- and post-mortem examinations of an affected pig and recorded his observations on local pig husbandry. Thompson's research (2000: 11) suggested that the pig deaths were the result of 'the combination of overpopulation of free-ranging pigs, inadequate nutrition and severe contamination by internal parasites', rather than pollution from the mine, although he identified elevated levels of lead and arsenic in the run-off from the processing plant. Thompson (2000: 12) recommended that Labarai creek be diverted away from Putput village, suggesting that otherwise it would remain a 'cause of concern and possible basis for compensation claims'.

Whereas Thompson absolved the mine from direct responsibility for the pig deaths, the residents of Putput rejected the mine's attempt to limit the issue to a simplified or shortened causal hypothesis, i.e. whether or not the pigs died as a result of exposure to toxic chemicals contained in the run-off from the processing plant. They argued that the mine owed them compensation for their pigs because the problems were the result of changes associated with mining on Lihir. To underscore their claim, the landowners threatened to close down the mine if compensation for their losses were not forthcoming.

Several months later an agreement was reached between the mine and the local community. The mine agreed to compensate the pig owners for outstanding claims. It also proposed to help remedy the conditions responsible for the porcine mortalities. What rationale did the mine present as the basis for its decision? A lengthy series of events linked the mine to the death of the pigs. Construction of the mine forced the people of Putput village to relocate. Their new land lacked sufficient resources to adequately feed and support the number of pigs that they owned. This resulted in 'severe malnutrition and worms infestation due to improper feeding and unhygienic condition[s] ... which the pigs encountered while in search of food', according to a memo written by a member of the mine's agricultural staff. While the mine was initially reluctant to compensate the people of Putput for their losses, pressure from the landowners forced the mine to address the complex chain of events through which it was connected to the pig deaths, leading it to accept partial liability for the losses of the people of Putput.

In a draft of the settlement agreement between the mine and the pig owners, this was expressed as: 'LMC [Lihir Management Company] and the community of Putput ... acknowledge that all parties must share the blame for the problem ...' The document included commitments from the mine to pay K17,640 in compensation for the 
lost pigs, institute a vaccination programme as recommended by veterinary authorities, conduct an educational programme regarding the care and feeding of pigs for the people of Putput village and undertake other actions in support of local pig husbandry as appropriate, including the monitoring of their health status until the current problems have abated.

That negotiations between the two parties took place under the threat of mine closure suggests that the events might be treated as a political contest. There is no doubt that the people of Lihir manoeuvre for favourable terms vis-à-vis the mine. But the question here is whether the two parties view compensation claims in the same way. Whereas the mine initially regarded the events in relatively narrow terms, focused on scientific evidence that failed to reveal a direct connection between the mine and the death of the pigs at Putput, the villagers rejected this view. They were able to force the mine to acknowledge its implication in a wider chain of events which had unintended and unfortunate consequences for the people of Putput.

\section{Networks and ownership}

It is instructive to consider this example in relation to a pair of essays by Marilyn Strathern $(1996,1998)$ on networks and property, which were written in response to Bruno Latour's (1993) We have never been modern. Latour argued that one of the distinguishing features of modern networks is their scale. Consumers and commodities are linked by economic relationships that encircle the globe; information technologies communicate ideas around the world effortlessly and instantaneously. In contrast to the expansionist tendencies of modern networks, Latour claimed that 'non-modern' social networks are limited in length. Strathern has questioned Latour's conclusions, suggesting that he neglected important differences in how societies construct social networks, especially the way in which Euro-American property claims reduce their length.

The compensation claims examined in this paper might be compared to patents or copyrights insofar as they all make statements about the ownership of things and/or ideas. In seeking to license scientific discoveries, claims to ownership are based on novel contributions to the invention in question, while ignoring pre-existing networks (the other scientists who have conducted research on the subject, but are excluded from the application for the patent). ${ }^{11} \mathrm{~A}$ patent thus restricts ownership (and profit) to the final segment of the network, neglecting the other contributors. Strathern (1996) described this process as 'cutting the network' and argued that Euro-American models of ownership operate by limiting the number of claimants to property. So whereas Latour described the propensity of modern networks to grow large, there is an important caveat to his observation, that Euro-Americans shorten these networks when they establish claims of ownership.

In contrast, social networks in Melanesia typically include all of those persons

11 Biagioli (1998: 11) made a comparable observation with regard to authorship: 'the focus on the individual author as the holder of such newfangled property rights misrepresented the long chain of human agency that produced a literary work ... [which was] seen as emerging from an instantaneous act of creativity, not from the time-extended labor of paper makers, font cutters, editors, typesetters, printers, binders, and booksellers (not to mention the body of previous literary works from which the author drew his/her "inspiration")'. 
who have contributed to another's success, each of whom may later lay claim to their share of what that person attracts in the transactions in which he or she participates. Whereas these networks may not expand to the physical scale of their Euro-American counterparts, claims of ownership are partial, multiple and overlapping, and thus do not necessarily reduce their overall length by restricting participation. ${ }^{12}$ Threats of sorcery, for example, which target persons who refuse to acknowledge their debts to others, can be seen to mitigate against the shortening of Melanesian networks.

These examples complicate Latour's arguments about the scale of networks. Both approaches to networks - of reducing their length in Euro-American property claims and of addressing a broader set of social relations in Melanesian compensation claims - are evident in the dispute over the pig deaths at Putput and the mine's response to the community. On the one hand, the mine originally viewed the problem solely in terms of limiting corporate obligations to local communities. No compensation was necessary because pollution from the mine did not kill the pigs. On the other hand, pressure from Lihirians forced the mine to acknowledge its involvement in the lengthy chain of events that led to the problems at Putput. The mine's initial response was to shorten the network, while the Lihirians brought the larger social network into view.

\section{Science, networks and compensation claims}

A central issue in disputes between mining companies and affected communities in Papua New Guinea is the association of science, like ownership, with shortened networks. Mining companies often use science to frame problems so that they relate directly to a 'natural world' that exists independently of social relations (see McEachern 1995). In response, landowners affected by mining companies have challenged the exclusivity of the resulting explanations, providing alternative perspectives which take social relations into account. ${ }^{13}$

In several cases, communities living downstream from large-scale mining projects have charged these mines with responsibility for problems that would otherwise have been attributed to sorcery or witchcraft. The Yonggom living downstream from Ok Tedi view the mine as a kind of corporate sorcerer because, like a sorcerer, it acts irrationally, behaves in an antisocial manner and endangers its neighbours (Kirsch 1997a). Their compensation claims against the mine have addressed a variety of misfortunes including an injured finger, a broken bone and a drowning after a canoe overturned that implicate the mine in social relations downstream. Yonggom sorcery accusations

12 Although corporate shareholders might be described as the archetype of multiple ownership in the west, they are joined by legal codes that treat the resulting entity as an individual. As Pietz (1997: 108) notes, the establishment of limited liability for investors in corporations 'represents the cultural production of a new kind of transhuman person (a corporation is a person in the eyes of the law) not subject to human mortality. The material assets of a corporation are owned by this entity and continue to be should any, or all, of its human owners die. In this, modern corporations are true immortal spiritual beings, as much as any god or sovereign. However, it is precisely their private status, the absence of the divinely legitimated power and the quasi-religious public duties of sovereignty, that distinguishes them'.

13 Disputes over the interpretation of the environmental impact of mining were critical factors in the onset of civil war on Bougainville (Connell 1991) and the legal battle over the Ok Tedi mine (Kirsch 1997b). 
critique the political economy of mining by framing compensation claims against the mine in terms drawn from the local moral economy.

Downstream from the Porgera mine in the southern Highlands, similar claims about sorcery have emerged (Haley n.d.). ${ }^{14}$ The assertions were initially limited to the deaths of a number of pigs thought to have consumed polluted river water. The deaths were blamed on 'poison', or sorcery, leading to the equation of pollution and poison, and of environmental impacts and sorcery more generally. The analogy was later broadened to include human fatalities, so that a number of deaths previously attributed to sorcery via 'poison' were retrospectively explained by pollution released into the river by the mine.

In both examples, the local communities attribute a range of problems to the effects of mining. In contrast, the mining companies look primarily to scientific evidence to evaluate their impact on the environment (and people) downstream. Environmental issues are amenable to positivist, empirical inquiry. Either it can be demonstrated that the mine has caused a particular problem, for example that run-off from the processing plant at Lihir killed the pigs at Putput, or the mine is absolved of responsibility. But neither questions about compensation claims for pig deaths at Lihir nor overturned canoes on the Ok Tedi river can be fully answered by science. The tendency for Euro-Americans to view environmental issues independently of social relations follows what Latour (1993:10-12) has identified as the modernist emphasis on the separation of categories (e.g. nature/culture, science/politics). ${ }^{15}$ Melanesians, however, are more apt to treat what Euro-Americans call the 'environment' as a hybrid, a combination of social relations and things in the world, in part a human creation, rather than an independent condition (e.g. the 'organic').

These examples suggest that some forms of science may be predicated in part on the same strategy that establishes ownership in property regimes, of cutting the network. Latour has emphasised the hybrid nature of modern networks, their ability to combine persons, things and ideas (e.g. scientists, arguments about global warming and refrigerator coolant) into a single chain. Yet when the scope of scientific inquiry is restricted, it cannot resolve problems that are hybrid in composition. In contrast, an emphasis on broader social networks may bring other issues into view.

\section{Lihir road kill}

When mining company vehicles kill domesticated pigs, which forage and move along the road that encircles the island, Lihirians demand compensation. A method for dealing with these circumstances is in place. A corporate representative is sent to negotiate with the owner of the animal, paying as much as $\mathrm{K} 1,000$ per pig. The rate varies according to the original investment (some animals are now brought from Rabaul and New Ireland by sea, at considerable expense), market value (based on size and matu-

14 Andrew Strathern (1997:7) observed that 'deaths [among Duna speaking people along the Strickland River] attributed to witchcraft in 1991 were diagnosed as caused by pollution in 1994, following visits by a loiya (lawyer)'. Stewart and Strathern (1997: 24, n.70) added that these deaths 'were now being traced to pollution from the Strickland river which had been running red from the discharge of oxides used in the gold mining process at the Porgera mine in the Enga Province'.

15 Latour (1993: 11) argued that modernist discourse 'establish[es] a partition between a natural world that has always been there, a society with predictable and stable interests and stakes, and a discourse that is independent of both reference and society'. 
rity at death) and projected value at maturity (if not fully adult). These principles are not necessarily applied with consistency; social factors (the identity of the driver and the owners of the vehicle and the pig) and other details of the accident may influence the amount paid in compensation.

A view expressed by some parties at the mine (both Melanesian and expatriate) is that compensation demands for pigs killed in road accidents are manipulated by Lihirians to extract additional funds from the mine, which is compelled to respond in order to maintain working relationships with surrounding communities. This position is supported by the observation that Lihirians seek compensation from the company for all pigs killed by motor vehicles on the road, even when they are not owned by the mine or driven by one of its employees. Lihirians claim that the mine is responsible for all vehicular accidents because it built the road, even though Lihirians requested its construction.

The underlying principle of liability has parallels elsewhere in Melanesia. David Akin (1999: 59) has described its invocation in the Solomon Islands, both in rural contexts in which the sponsors of feasts are 'liable for misfortune befalling those who attend social events they create' and in urban areas in which 'the government is liable for trouble that occurs ... because the town is a government creation'. In each of these examples - the mine held accountable for accidents along the road, the sponsor of a feast for mishaps and the government for urban crime and conflict - social networks link specific losses to the person(s) or agent(s) responsible for the context (the road, the feast, the town) in which the events occurred, regardless of their separation in time or the actions of other agents in the interim. In all of these claims, social networks are stretched to their logical limits.

Despite holding the mine responsible for all of the accidents along the road, Lihirians themselves are critical of the mine's practice of paying compensation on behalf of its employees. The landowner association argues that the driver of the vehicle involved in an accident, rather than the mine, should compensate the owner of the pig. They suggest that holding the drivers personally accountable would reduce the number of accidents.

Gender is also a factor in compensation claims and payments. Macintyre (2000) observed that compensation claims are always made by individual men, even though pigs are either the property of families (with multiple ownership crossing gender lines) or individuals, with women having rights to an equivalent number of pigs as men. The money gained through compensation claims is also individually controlled and consumed, rather than circulated or re-invested. Women are typically denied access to these funds, even when they were directly responsible for the care and feeding of the pigs. Social networks associated with compensation claims may contract along gender lines when their losses are converted into cash.

These examples illustrate that Lihirians are not limited to a single strategy vis-àvis social networks when making compensation claims. They argue that the mine is responsible for all of the pigs killed along the road, construing the network as broadly as possible (while presumably avoiding negotiations with fellow Lihirians, along with the networks that they might activate). Yet when they assign individual responsibility to drivers for accidents, they reduce the network to its shortest possible configuration. The Lihir mine, it might be added, also employs both strategies: shortening the network to reject responsibility for accidents which do not include either company vehicles or personnel, while lengthening the network to assume responsibility for all 
claims against its employees. These are strategic decisions; miners and Lihirians alike may either shorten or lengthen social networks according to the circumstances and their objectives.

\section{Compensation}

A key element of compensation claims against Lihir is the threat of mine closure. Colin Filer (1997: 176) described how an executive at the mine once considered purchasing large quantities of shell valuables for the company to distribute at local mortuary feasts, although the plan was never implemented, perhaps because it would have involved the mine too closely in local affairs. Yet the mine has granted considerable power to the local practice of gorgor, the Tok Pisin name for a plant used to demarcate taboo zones (e.g. gardens, an unoccupied house or one's hunting grounds) in which people are forbidden to trespass. Tying gorgor to the gates of the Lihir mine stops production because its employees not only understand but also obey the message. By respecting this local signal the mine also legitimises the underlying claim that its operation is contingent on the continued goodwill of the local community.

Compensation claims are deployed throughout Melanesia to express concerns about a variety of political, economic and environmental concerns. Rural communities use the threat of disruption or violence to establish a forum external to formal political channels through which they can negotiate on their own behalf. ${ }^{16}$ Whereas compensation demands expand the possibilities for local participation, they undermine the authority of the state to regulate and distribute resources (Filer 1997). That the state is unable to prevent landowners from exercising veto power over resource developers is one of the lessons that can be drawn from the decade of civil war that followed the forced closure of the Panguna mine on Bougainville by local residents (Filer 1990). ${ }^{17}$ Without a mutually-recognisable signal like the gorgor, relationships between resource developers and affected communities may deteriorate quickly, resulting in conflict and violence.

Several anthropologists have proposed mechanistic metaphors to characterise aspects of the compensation process in Papua New Guinea. Filer (1997:189) suggests that compensation discourse 'functions like a thermostat which measures and controls the heat or friction generated by the differential local impact of [resource development]'. He argued that economic responses to compensation claims cannot solve problems that are inherently political, as "landowners are not interested in a "fair price" for their resources, or a reasonable "trade-off" between financial and political rewards, but seek to do away with every form of wealth or power which makes them seem to be dependent or inferior in their relations with “their” developers' (Filer 1997:

16 See Filer (1995) for a discussion of Lihirian participation in the negotiation of this compensation package for the Lihir gold mine.

17 Emphasising the coercive elements of these claims, Filer (1997: 173) compared landowners seeking compensation to the infamous raskals (criminals or gang members) who operate along the road through the central highlands of Papua New Guinea, 'There is less reason for developers to hope that landowners demanding compensation are on their way to becoming petty landlords collecting a reasonable return, and more reason to suspect that "compensation" is another name for extortion, and thus a form of theft rather than a form of rent, whose collection is hardly to be distinguished from the "gate-keeping" practices of the hold-up merchants along the Okuk Highway'. 
182). Strathern (1999:188-9, 291, n.15) suggests that compensation is like a 'universal translator' which, under certain circumstances, can convert anything into wealth. ${ }^{18}$ Whereas both of these analogies have their virtues, I suggest an alternative model, which begins with the recognition that compensation implies an evaluation of the property in question, although the strategy for calculating this value may differ between the two parties.

Significantly, it is not the compensation claim that establishes the value of the property in question, but rather what is given in response, suggesting a relationship that can easily become unbalanced. Instead of a thermostat (measuring conflict) or a universal translator (converting property claims into money), imagine a pair of counters, representing the two parties to the compensation claim, which are expected to interdigitate, but do not always properly interface. Sometimes they seem to be in sync with one another (e.g. when compensation claims made by Lihirians and corresponding offers from the mine are not substantially different), so that their operation appears to be the same on both sides. On other occasions, however, one of the counters may rotate slowly or not at all (e.g. when it was determined that pollution from the mine did not kill the pigs from Putput and therefore the mine owed nothing to their owners), while its counterpart spins rapidly (e.g. the unrelenting demands for compensation for their pigs from the Putput landowners), failing to find the complementary notch (or point of compromise) that would bring the two sides back into sync. At this point, the gorgor is the spanner thrown into the works that stops the process, allowing for recalibration.

Obviously each of these imaginary machines (the thermostat, the universal translator and the interconnected counters) models a different aspect of the compensation process. But I will stay with the metaphor of the two counters, sometimes in phase with each other, while at other times wildly out of sync, because it enables me to make an important point that has not been given sufficient attention in the literature to date. To understand the relationship between the two parties in compensation claims requires sensitivity to differences in the production of value in property and transaction regimes, as the third and final example from Lihir illustrates.

\section{Mortuary exchange on Lihir}

The pigs raised by the villagers from Putput were intended for transactions associated with inter-clan feasts held for major life-cycle events, of which mortuary rituals are the most significant. The value of the pigs distributed at these feasts may be calculated in terms of strings of shells known as mis in Tok Pisin. According to Martha Macintyre (n.d.), the production and distribution of both pigs and shells has increased significantly with the influx of cash from the mine. Macintyre described mis as 'genuine shell currency' comparable to Tolai tambu: it is divisible, used in everyday and ritual contexts, and functions as a standard across competing spheres of exchange.

18 Strathern (1999: 188) described compensation as 'refer[ring] both to the payment owed to persons and to procedures by which they come to negotiate settlement. It can thus cover recompense due to kin for nurture they have bestowed, as in bridewealth, as well as damages, as in reparations to equalise thefts or injuries. It can substitute for a life, in homicide compensation, or for loss of resources. Car fatalities, war reparations, mining royalties: all potentially fall under its rubric ... Liabilities and claims are defined by the positions parties take in relation to one another over the issues of compensation itself'. 
Macintyre (n.d.) also observed that Lihirians increasingly travel to New Ireland to buy pigs at inflated values. On Lihir, producing pigs from cash is now an effective substitute for raising pigs oneself. Whereas being a 'big man' was once synonymous with owning many pigs, big men now compel workers to purchase animals on their behalf. She noted that:

Lihirians will travel to Tanga or Tabar or Namatanai and pay up to K1,000 (and numerous mis) for a pig that would cost less than half that on Lihir. The pig is usually large ... but often indistinguishable from others acquired for less. At the feast this pig will be given and its very high cash value made known, so that the counter prestation will have to involve a pig that has been purchased for the same amount of money and mis. The economic 'irrationality' of this trend is not conceded. ${ }^{19}$

The expenses required to procure pigs from other islands greatly inflates their value. Yet one's entire investment is measured in the subsequent transaction. In other words, it takes more than a pig of comparable worth to provide an equivalent exchange, it requires a comparable investment. Macintyre referred to this as 'irrational' or noneconomic.

Mortuary feasts on Lihir account for the value placed on pigs above and beyond their economic worth and for local engagement in non-economic forms of exchange. C. A. Gregory (1997: 56) has analysed a sequence of transactions that preceded a Trobriand funerary ritual in which income earned from the sale of carvings to tourists is transferred into the realm of gift exchange: 'This roundabout way of acquiring a gift keeps the alien world of commodities at bay, not by erecting a cordon sanitaire around the island, but by providing a means by which commodities can become domesticated into gifts'. The same logic applies on Lihir: while accepting the monetisation of daily life associated with the mine, they reject the application of these values to mortuary exchange, which threatens to transform their rituals into monetary assessments of the value of human life. Foster (1995: 248) made a comparable claim regarding neighbouring Tangans in respect of the strict separation they maintain between mortuary ritual and commerce: 'The distinction between kastom and bisnis in Tanga was the result of a confluence of historical factors. But it was also the result of a perceived incompatibility of commodity production and the processes of social reproduction that they underpin'.

The pigs exchanged by Lihirians at their feasts can be described as embodying a series of transactions or a network of social relations. Lihirians measure relations with one another through pigs and what is being evaluated is the work and agency that is required to bring a pig to the feast, or today to produce pigs in the context of new social and economic conditions associated with the mine. This takes the form of social networks that are in effect contained within the pigs.

An analogy can be made between these exchanges and compensation claims made against the mine. When Lihirians claim compensation from the mine for one of their pigs, they also seek recompense for the network of social relations embodied in the animal. Compensation payments should adequately address their work and agency in producing the pig in addition to potential relationships (also contained within the pigs) that have been abrogated. In the Putput example, the manner in which the pigs

19 Macintyre (n.d.) indicates that these payments can be seen as a means of redistributing cash from wage earners and the recipients of royalty payments to persons with less access to cash. 
died invoked a series of events (including their relocation by the mine, problems with the land on which they grazed their pigs etc.) that were also embodied in these animals. In seeking compensation for their pigs, Lihirians brought these (otherwise concealed) networks into view.

\section{Conclusions: property, compensation and the value of human life}

Compensation claims on Lihir provide an informative context through which to evaluate the debate between Marilyn Strathern and Bruno Latour regarding social networks. Latour overlooked relations of power among people who occupy different nodes along a network; Euro-American claims of ownership work (in part) by cutting networks short, whereas compensation claims in Melanesia typically bring social relationships into view. It is important to note, however, that these are relative emphases rather than essential differences; as the disputes over compensation for pigs killed along the road in Lihir illustrate, either party may (temporarily) favour exclusivity over incorporation.

Whereas Strathern depicted these networks in social terms, as persons and their extended parts which take the form of objects, Latour emphasised their heterogeneity. ${ }^{20}$ That these networks incorporate a range of persons, things and ideas may account for the failure of (relatively narrow) scientific explanations to satisfy many Papua New Guineans about the environmental impact of mining projects. The length of social networks on Lihir is also evident in the transactions associated with their mortuary feasts. The value of the pigs given in mortuary rituals represents the work and agency required to produce pigs through monetary relations in the new world created around the mine. In all of the examples presented here, however, it is instructive to think of pigs on Lihir not only in terms of their monetary value, but also as embodying the social networks through which they were produced and the possibility of future relationships.

To expand on the comparison of ownership claims in property and transaction regimes, I return to Pietz's (1997) analysis of nineteenth-century reforms of British legal categories associated with property, compensation and the value of human life. How do new economic forms like railways and mines influence the way that property and ownership are defined? Pietz (1997: 100) notes that the new technologies of the industrial revolution increased the frequency of accidents as the unintended conse-

20 Gell (1998: 222-3) provided an elegant summary of M. Strathern's (1988) position on the 'distributed person': '[If] we try to give an account of the external aspect of persons, we find that any one social individual is the sum of their relations (distributed over biographical time and space) with other persons. Our inner personhood seems to consist of replications of what we are externally ... So, bearing this in mind, it may not be so aberrant to suggest that what persons are externally (and collectively) is a kind of enlarged replication of what they are internally. [We can] consider "persons" not as bounded biological organisms, but use this label to apply to all the objects and/or events in the milieu from which agency or personhood can be abducted. Seen in this light, a person and a person's mind are not confined to particular spatio-temporal co-ordinates, but consist of a spread of biographical events and memories of events, and a dispersed category of material objects, traces, and leavings, which can be attributed to a person and which, in aggregate, testify to agency and [personhood] during a biographical career which may, indeed, prolong itself long after biological death. The person is thus understood as the sum total of the indexes which testify, in a life and subsequently, to the biographic existence of this or that individual'. 
quences of mechanical operation. The resulting injuries (and sometimes deaths) established new monetary relations between corporations and individuals.

Both prior to and after the abolition of the deodand, the social networks associated with compensation payments for railway accidents were limited in length. In the first instance, the value of compensation was arbitrarily fixed by the 'value of the [material] instrument of injury', i.e. the ox that gored or the cart that overturned. The deodand was in part a solution to the problem of compensation without activating any of the relevant social networks. It was rescinded when its costs became prohibitive, raising new questions of scale in relation to the respective values of technology and human life. The legal substitute for the deodand (compensation payments based on the loss of potential earnings) failed to engage with questions about the safety of the technology employed or the added risks that might be incurred from the pressure to keep the trains to schedule. The relatively new notion of limited liability for corporations also shortened the social networks that might otherwise have been invoked in the event of an injury or death.

The examples from Lihir present a valuable point of comparison with the railway accidents analysed by Pietz. His essay referred to people who were killed by locomotives, compensation payments calculated by the insurance industry and the reduction of social networks. The examples from Lihir involve pigs killed in road accidents and by poor grazing conditions, compensation payments negotiated under the threat of gorgor and references to wider social networks. While the decision to abolish the deodand eased the way for trains (and capital) to circulate unimpeded, the unsynchronised 'counters' of Lihirian compensation claims are the result of different strategies of ownership and alternative ways of calculating value.

In an essay on colonialism in the Papuan Highlands, Eric Hirsch (1999: 825) drew attention to a related contrast between Australian colonial attempts to 'discipline the social and material world so that it renders discrete units for administrative efficacy and authority' and how the Fuyuge 'perceive relatively little value in the reproduction of discrete units with individual identity'. Similarly, conflicts between Lihirians and the mine reflect fundamental differences in how the two parties conceptualise value.

Pietz (1997: 104) has shown how fatal accidents and legal reforms combined to establish novel debt liabilities and new monetary values, illustrating that 'death, the destruction of life, the very antithesis of an economically productive event, sometimes creates money'. The reform of the deodand produced new relationships between money and people: it established a monetary value for human life. Pietz (1997: 108) explains how this monetary value is experienced:

Capitalism can fully establish itself as the structuring system of a social reality only to the extent that monetary debt in this sense becomes a practical logic and 'felt necessity' in everyday social interactions. It may be that the historical limits of capitalist relations appear in those traumatic events that fall outside the economic realm of commercial exchange and contractual agreement, but whose material impact on individual human lives, in cases of accidental injury, and on whole peoples, in the form of war, nevertheless valorise new debt relations that the modern social order must somehow realise in the form of monetary value.

While nineteenth-century British law established a new monetary value for human life, Lihirians have an alternative institution that accounts for the value of human life: mortuary feasts in which the pigs that are exchanged measure the (social) worth of the 
deceased. ${ }^{21}$ By rejecting the application of monetary (or commodity) logic to the objects that circulate in their mortuary rituals, Lihirians reject the monetary value of human life..$^{22}$

In order to understand the relationship between property, compensation and the value of human life, one may examine the historical transformations of monetary value, as Pietz does for nineteenth-century Britain, or the meeting point of alternative systems of value (what I refer to as property and transaction regimes). A key difference in how these values are realised is the respective strategies of ownership employed in each case, mobilising networks that vary in length. The way in which ownership claims are formulated affects other social categories, including the narrowness with which scientific problems may be defined and how one measures the value of life. These 'property effects' are of considerable interest and import, whether they refer to compensation for railway accidents in nineteenth-century Britain or pigs destined for mortuary feasts in Lihir which are accidentally killed along the road built by the mine.

Finally, I return to property and transaction regimes as an alternative to the distinction between gifts and commodities. An analysis formulated in terms of gifts and commodities might emphasise Lihirian resistance to the commodification of pigs (and of social life more generally). ${ }^{23}$ But the dispute between Lihirians and the mine is not simply about the standing of these objects (the pigs) as gifts or commodities. What is at stake is the character of the social networks organised through these modes of exchange. Where social reproduction is carried out through transactions - in contradistinction to property relations which emphasise consumption rather than circulation there may be resistance to the shortening of social networks rather than commodification per se. I do not dispute that Lihirians seek to maximise their returns from the mine in the form of compensation, but I argue that they also seek to protect the capacity of their mortuary feasts to measure the value of life in terms of other human relationships. Whereas property claims generally reduce the length of the networks involved, these transactions are the means by which Lihirians keep social relations in view.

Stuart Kirsch

Department of Anthropology

University of Michigan

Ann Arbor

Michigan 48109

USA

21 Note that Foster (1995: 170; emphasis removed), following M. Strathern, described exchange in Melanesia as 'a process in which agents construct particular differences (or similarities) relative to each other - instead of the equal value or equivalence of their object - through the circulation of specific items in specific contexts'.

22 Another way to put this is that the measure of life cannot be money, which cannot reproduce itself in the same way that pigs and shells do in a Melanesian context, an assertion that is strikingly similar to feudal claims about money (see Pietz 1997: 102-3). As Foster (1995: 224) noted, 'Mortuary feasting ... is nothing less than the alternation of life and death, the transformation of one into the other'.

23 Strathern and Stewart (1998: 58) have argued that 'pigs [in Hagen] are not fully commoditized: their status as substitutes for human life remains intact because they have no place in the outside system other than as an occasional trading resource'. They also note (p. 63) that 'Compensation practices recognize the substitutability of wealth for the person, and contemporary problems reveal the incipient commodification of the person-body complex resulting from the effects of monetization in the economy at large'. 


\section{References}

Akin, D. 1999. 'Compensation and the Melanesian state. Why the Kwaio keep claiming', The Contemporary Pacific 11: 35-67.

Appadurai, A. 1988. 'Introduction. Commodities and the politics of value', in A. Appadurai (ed.), The social life of things. Commodities in cultural perspective, 3-63. Cambridge: Cambridge University Press.

Banks, G. 1998. 'Compensation for communities affected by mining and oil developments in Melanesia', Malaysian Journal of Tropical Geography 29: 53-67.

Biagioli, M. 1998. 'The instability of authorship. Credit and responsibility in contemporary biomedicine', Life sciences forum, FASEB Journal, 12: 3-16.

Bloch, M. and J. Parry. 1991. 'Introduction. Money and the morality of exchange', in J. Parry and M. Bloch (eds.), Money and the morality of exchange, 1-32. Cambridge: Cambridge University Press.

Carrier, J. G. 1995. Gifts and commodities. Exchange and western capitalism since 1700. London: Routledge.

Connell, J. 1991. 'Compensation and conflict. The Bougainville copper mine, PNG', in J. Connell and R. Howitt (eds.), Mining and indigenous peoples in Australasia, 55-75. Sydney: Sydney University Press.

Filer, C. 1997. 'Compensation, rent and power in Papua New Guinea', in S. Toft (ed.), Compensation for resource development in Papua New Guinea, 156-190. Port Moresby and Canberra: Law Reform Commission of Papua New Guinea (Monograph no. 6) and National Centre for Development Studies (Pacific Policy Paper 24).

1995. 'Participation, governance and social impact. The planning of the Lihir gold mine', in D. Denoon, C. Ballard, G. Banks and P. Hancock (eds.), Mining and mineral resource policy. Issues in Asia-Pacific prospects for the 21st Century, 67-75. Canberra: Australian National University.

1990. 'The Bougainville rebellion, the mining industry and the process of social disintegration in Papua New Guinea', in R. J. May and M. Spriggs (eds.), The Bongainville crisis, 73-127. Bathurst: Crawford House Press.

Foster, R. J. 1995. Social reproduction and history in Melanesia. Mortuary ritual, gift exchange and custom in the Tanga Islands. Cambridge: Cambridge University Press.

Gell, A. 1998. 'Conclusion. The extended mind', in A. Gell, Art and agency. Towards a new anthropological theory, 221-58. Oxford: Clarendon.

Gregory, C. A. 1982. Gifts and commodities. London: Academic Press.

1997. Savage money. The anthropology and politics of commodity exchange. Amsterdam: Harwood.

Haley, N. n.d. 'Polluting desires', unpublished paper presented at the conference, Cosmology and Development in Melanesia, James Cook University, Cairns.

Hirsch, E. 1999. 'Colonial units and ritual units. Historical transformations of persons and horizons in highland Papua', Contemporary Studies in Science and History, 41: 805-28.

Hyndman, D. 1994. Ancestral rain forests and the mountain of gold. Indigenous peoples and mining in New Guinea. Boulder: Westview.

Kirsch, S. 1997a. 'Indigenous response to environmental impact along the Ok Tedi river', in S. Toft (ed.), Compensation for resource development in Papua New Guinea, 143-155. Port Moresby and Canberra: Law Reform Commission (monograph no. 6) and National Centre for Development Studies (Pacific Policy Paper 24).

1997b. 'Is Ok Tedi a precedent? Implications of the settlement', in G. Banks and C. Ballard (eds.), The Ok Tedi settlement. Issues, outcomes and implications, 118-140. Canberra: National Centre for Development Studies (Pacific Policy Paper 27).

Latour, B. 1993. We have never been modern, translated by Catherine Porter. Cambridge: Harvard University Press.

McEachern, D. 1995. 'Mining meaning from the rhetoric of nature. Australian mining companies and their attitudes to the environment at home and abroad', Policy Organisation and Society 10: 48-69.

Macintyre, M. 2000. Personal communication.

n.d. 'Substitutions and transformations in exchange systems in the context of economic change. Gifts and money on Tubetube and Lihir', unpublished paper. 
Pietz, W. 1997. 'Death of the deodand. Accursed objects and the money value of human life', Res 31: 97-108.

Post Courier of Papua New Guinea. 1998. 'Locals at Lihir shut mine for short time'. Finance, Post Courier of Papua New Guinea, 7 July.

Rio Tinto. 1997. Rio Tinto 1997 annual report to sharebolders. London: Rio Tinto plc and Rio Tinto Ltd.

Stewart, P. J. and A. Strathern. 1997. 'Sorcery and sickness. Spatial and temporal movements in Papua New Guinea and Australia'. James Cook University Discussion Papers 1, 1-27.

Strathern, A. 1997. 'Compensation. Or moving swiftly over broken ground', in S. Toft (ed.), Compensation for resource development in Papua New Guinea, 1-9. Port Moresby and Canberra: Law Reform Commission of Papua New Guinea (Monograph 6) and National Centre for Development Studies (Pacific Policy Paper 24).

Strathern, A., and P. J. Stewart 1998. 'The embodiment of responsibility. "Confession" and "compensation” in Mount Hagen, Papua New Guinea, Pacific Studies 21:43-64.

2000. 'Accident, agency, and liability in New Guinea highlands compensation practices' $B K I$ 156(2):275-95.

Strathern, M. 1988. The gender of the gift. Berkeley: University of California Press.

1996. 'Cutting the network', Journal of the Royal Antbropological Institute 2: 517-35.

1998. 'The new modernities', in V. Keck (ed.), Common worlds and single lives. Constituting knowledge in Pacific societies, 379-403. Oxford: Berg.

1999. 'What is intellectual property after?', in M. Strathern, Property, substance and effect. Anthropological essays on persons and things, 179-203. London: Athlone.

Thompson. Dr. 2000. 'Investigation of pig mortalities Lihir Island, 20-23 January 2000 Preliminary report', unpublished report.

Weiner, A. 1980 'Reproduction. A replacement for reciprocity', American Ethnologist 7: 71-85. 